\title{
$\mathrm{RAPD}$ 마커를 이용한 한국밀의 유전적 다양성 평가 및 품종 판별
}

\author{
손재한 - 정영근 - 박종철·김양길 - 박종호 - 김경호 - 박태일 - 김보경·강천식 ${ }^{*}$ \\ 농촌진흥청 국립식량과학원 작물육종과
}

\section{Assessment of Genetic Diversity and Identification of Korean Wheat Varieties using RAPD Markers}

\author{
Jae-Han Son, Young-Keun Cheong, Jong-Chul Park, Yang-Kil Kim, Jong-Ho Park, Kyong-Ho Kim, \\ Tae-Il Park, Bo-Kyeong Kim, and Chon-Sik Kang \\ Crop Breeding Division, National Institute of Crop Science, RDA, Wanju, 55365, Korea
}

\begin{abstract}
Eleven RAPD primers were assessed to analyze genetic diversity of Korean wheat varieties and to develop DNA marker for cultivar identification. The average of the number of polymorphic bands was 5.2 and PIC values showed 0.48 , respectively. Ten major clades were presented by phylogenetic analysis. Three cultivars containing Uri, Hanbeak and Jonong were distinct from the others in the phylogenetic dendrogram. Seven cultivar-specific fragments were detected from 11 RAPD fingerprinting among 35 wheat cultivars and they were sequenced. Four Korean wheat cultivars, Eunpa, Jopoom, Yeonbaek and Jeokjoong, were identified newly by four markers, 84, 173, 174 and KWSM011. We convince that these new DNA markers are useful for cultivar fingerprinting and are applied to marker-assisted selection in wheat breeding program.
\end{abstract}

Keywords : Diversity, Molecular marker, RAPD, Wheat

\section{서 언}

밀은 세계적으로 중요한 식량작물 중 하나로서 연간 600 만톤 이상이 생산되고 있으며 세계 인구의 $40 \%$ 이상이 밀을 식량으로 이용하고 있고(Gupta et al. 2008), 한국에는 35개의 한국밀 품종이 개발되어 있다(Son et al. 2013). 밀은 A, B, D 등 서로 다른 게놈을 포함하는 6 배체 식물이다. 이 같은 특징으로 작물의 유전체 연구 모델로서 유용하기 때문에 세계적으로 밀의 연구가 활발히 진행되고 있고, 국내에서도 밀의 품질 및 품종특성 분석 등에 분자마커를 적용하고 한 연구가 진행되고 있다(Park et al. 2009).

동물 및 식물의 기초 및 응용 연구는 다양한 분자마커 (Molecular marker)의 개발에 의해 눈에 띄게 발전되었다. 분자 마커는 작물의 유전자 및 염색체 지도 작성 등에 유용하고, 응용 적인 면이나 편의성, 경제성 등에서 매우 효과적으로 사용되고

\footnotetext{
*Corresponding Author (E-mail: kcs1209@korea.kr, Tel: +82-63238-5227)
}

(Received on March 14, 2017. Accepted on April 20, 2017.)
있다. 작물의 유용형질 등과 연관된 유전적 특성은 환경의 영향을 거의 받지 않기 때문에 유용형질과 관련된 분자마커를 이용한 간접적인 선발은 작물육종에 매우 효과적이다(Kuchel et al. 2005). PCR법의 개발은 다양한 분자마커 기술개발의 촉진제가 되었으며, 생물정보학(Bioinformatics)의 발달로 인해 분자마커 는 지금까지 유전자 지도 작성 및 진단, 형질전환체 분석, 게놈연 구, 종간 유연관계 및 계통분석 등에 유용하게 사용되고 있다 (Rafalski et al. 1993).

Randomly amplified polymorphic DNAs(RAPDs)는 일반 적으로 10 nucleotide의 짧고 무작위적인 프라이머를 이용하여 $\mathrm{PCR}$ 을 수행하는 방법으로 분석이 간단하고 적은 양의 DNA가 있어도 분석이 가능하다(Williams et al. 1990). RAPD와 Denaturing gradient gel의 조합은 더욱 세밀한 DNA 다형성 분석을 가능하게 하였고, 밀의 재배종 간의 특성 구별을 위해 사용되기도 하였다(He et al. 1992, Dweikat et al. 1994). 또한 $\mathrm{RAPD}$ 는 유전자 지도 작성, 유전자 분리, 재배종 구분, 집단 및 종간의 유전적 다양성 분석(Chalmers et al. 1992, Nesbitt et al. 1995), 종간 또는 속간의 계통학적 유연관계 분석(Landry 
Table 1. 35 Korean wheat cultivars used in this study.

\begin{tabular}{cccccc}
\hline No & Cultivar & No & Cultivar & No & Cultivar \\
\hline 1 & Ol & 13 & Seodun & 25 & Baekjoong \\
2 & Geuru & 14 & Saeol & 26 & Jeokjoong \\
3 & Dahong & 15 & Jinpoom & 27 & Sugang \\
4 & Chungkye & 16 & Milsung & 28 & Hanbaek \\
5 & Eunpa & 17 & Joeun & 29 & Suan \\
6 & Tapdong & 18 & Anbaek & 30 & Dajoong \\
7 & Namhae & 19 & Jopoom & 31 & Goso \\
8 & Uri & 20 & Shinmichal & 32 & Hojoong \\
9 & Olgeuru & 21 & Jonong & 33 & Baekchal \\
10 & Alchan & 22 & Jokyoung & 34 & Jojoong \\
11 & Gobun & 23 & Yeonbaek & 35 & \\
\hline
\end{tabular}

Table 2. Information of RAPD markers used in this study.

\begin{tabular}{cccc}
\hline Name & Sequence $\left(5^{\prime} \rightarrow 3^{\prime}\right)$ & Number of amplified bands & PIC $^{\mathrm{z}}$ \\
\hline 84 & GGGCGCGAGT & 7 & 0.06 \\
173 & CAGGCGGCGT & 6 & 0.10 \\
174 & AACGGGCAGC & 6 & 0.99 \\
B12 & CCTTGACGCA & 2 & 0.00 \\
B18 & CCACAGCAGT & 5 & 0.74 \\
OPG5 & CTGAGACGGA & 9 & 0.00 \\
OPGQ1 & GGGACGATGG & 9 & 0.96 \\
OPH20 & GGGAGACATC & 2 & 0.66 \\
OPI01 & ACCTGGACAC & 4 & 0.74 \\
UBC106 & CGTCTGCGGG & 5 & 0.92 \\
RAPD14 & CGTCTGCCCG & 2 & 0.16 \\
\hline Mean & & 5.2 & 0.48 \\
\hline
\end{tabular}

${ }^{\mathrm{z}}$ PIC: Polymorphism information content

et al. 1994) 등 여러 분야의 연구에 이용 되었다. 이와 같은 연구는 종특이적(Chen et al. 1998), 게놈 특이적 또는 염색체 특이적(Wang et al. 1995) 마커 개발의 발전을 이끌었으며 특히 육종 과정 동안 분리된 집단에서 가능성 있는 유전자형을 확인하 고, 유용계통을 선발하기 위한 분자마커 개발 등에 사용되었다. $\mathrm{RAPD}$ 기법은 또한 식물의 스트레스 관련 유전자 동정을 위한 다형성 분석에 응용되기도 하였다(Pakniyat \& Tavakol 2007).

본 연구는 RAPD 분석법을 이용하여 한국 밀 품종 간 다형성 분석을 통하여 다양성 분석 및 품종 특이적 분자마커를 개발하기 위해 수행되었다.

\section{재료 및 방법}

\section{Genomic DNA 추출}

국내에서 육성된 35개 밀 품종의 종자를 페트리디쉬에서 발아
시켜 약 $5 \mathrm{~cm}$ 크기로 자란 어린잎을 이용하였다. 채취한 잎을 액체질소에 급속 동결하여 플라스틱 스틱으로 마쇄한 후 Genomic DNA extraction Kit for plant (SolGent, Korea)를 이용하여 제품의 추출 방법에 따라 수행하였다(Table 1). 추출된 DNA는 nono drop을 이용하여 각각 $20 \mathrm{ng} / \mathrm{ul}$ 의 농도로 정량하여 사용하였다.

\section{$\mathrm{RAPD}$ 다형성 분석}

$\mathrm{RAPD}$ 프라이머는 이미 여러 연구에서 공개된 것 중에서 다형성을 보이는 것을 선발하여 사용하였다(Table 2). PCR은 전체 $100 \mathrm{ng}$ 의 $\mathrm{DNA}$ 를 주형으로 하여, 프라이머 $0.5 \mu \mathrm{mol}$, dNTP $0.2 \mathrm{mM}$, Taq DNA polymerase 1 unit(GenetBio., Korea) 의 조성으로 수행하였다. $\mathrm{PCR}$ 조건은 denature; $94^{\circ} \mathrm{C}, 30$ 초, annealing; $40^{\circ} \mathrm{C}, 30$ 초, extension; $72^{\circ} \mathrm{C}, 1$ 분으로 40 회 반복하였 고, $1.5 \%$ 아가로스젤에 전기영동 한 후 다형성을 확인하였다. 


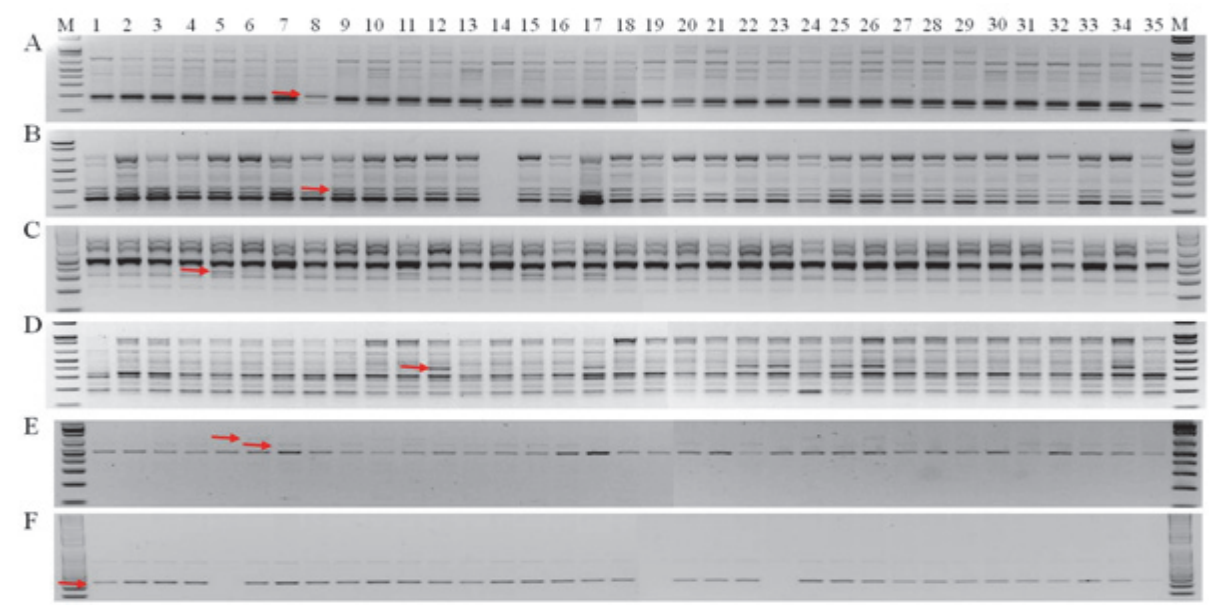

Fig. 1. RAPD analysis of 35 Korean wheat cultivars. Sizes of the amplified products range from 100 to $1,000 \mathrm{bp}$. The number and red arrows indicate Korean wheat cultivar-specific DNA fragments, respectively. The species specific DNA bands representing red arrows were eluted from agarose gel and sequenced. A; 84, B; 173, C; 174, D; OPGQ1, E; OPH20, and F; RAPD14. M; $1 \mathrm{~kb}$ plus ladder.

Polymorphism information content(PIC)는 PIC $=1-\sum_{\mathrm{i}=1}^{\mathrm{n}} \mathrm{pi}^{2}$ 으 로 계산하였다(Liu, 1998).

\section{클로닝 및 염기서열 분석}

전기영동에서 확인된 밴드 중 품종에서 특이적으로 증폭된 밴드(300 - 1,000 bp)는 agarose gel로부터 분리한 후 DNA fragment purification kit(Intron, Korea)를 사용하여 DNA를 추출하였다. 정제된 DNA 단편은 pGEM-T vector(Promega, $\mathrm{USA}$ )에 결합한 후 competent cell(DH5a competent Escherichia coli cells)에 형질전환 시켜 배양하였다. 배양된 세포로부터 plasmid DNA를 다시 추출한 후 염기서열 분석을 수행하였다(Genotech, Korea). 염기서열의 유전적 정보 등은 $\mathrm{NCBI(http://www.ncbi.nlm.nih.gov/)} \mathrm{웹사이트를} \mathrm{이용하여} \mathrm{분}$ 석하였다.

\section{유전적 유연관계 분석}

RAPD 다형성 분석을 위해 밴드로 증폭된 것을 ' 1 ', 증폭되지 않은 것을 ' 0 '으로 코드화 한 후 NTSYS-pc 2.0 프로그램을 이용하여 통계적 분석을 수행하였다(Rohlf 1998). 품종 간 연관 관계는 unweighted pair-group method on arithmetic averages(UPGMA)로 나타냈다.

\section{분자마커 제작 및 품종 적용}

품종 특이적으로 발현된 밴드의 염기서열을 이용하여 프라이머
를 디자인하기 위해 Primer3 (http://bioinfo.ut.ee/primer3-0.4.0/) 프로그램을 이용하였다. 증폭산물의 조건은 $300-600 \mathrm{bp}, \mathrm{Tm}$ $\left({ }^{\circ} \mathrm{C}\right)$ 은 $55-60^{\circ} \mathrm{C}$ 로 설정하여 프로그램을 실행하였다. 제작된 프라이머는 DNA 마커로서 35 개 국내 육성 밀 품종 판별 분석에 적용되었다. 품종 판별을 위한 $\mathrm{PCR}$ 조건은 denature; $94^{\circ} \mathrm{C}$, 30 초, annealing; $62^{\circ} \mathrm{C}, 30$ 초, extension; $72^{\circ} \mathrm{C}, 1$ 분으로 35 회 반복하였으며, $\mathrm{PCR}$ 산물은 $1.5 \%$ 아가로스젤에서 확인하였다.

\section{결과 및 고찰}

\section{$\mathrm{RAPD}$ 다형성 분석}

다형성분석에 사용된 PCR 산물은 $100-1,000 \mathrm{bp}$ 사이에서 증폭된 것으로서 밴드의 수와 크기를 분석하였다 (Table 2). 전체 57 개의 밴드가 확인되었고, 프라이머 별 평균 5.2개, 최소 2 개에서 최대 9 개의 다형성 밴드가 나타났다. 각각의 다형성 밴드는 84번 프라이머에서 7개, 173 번과 174번에서 6개, OPG5 와 $\mathrm{OPGQ} 1$ 에서 가장 많은 9개, $\mathrm{B} 18$ 과 $\mathrm{UBC} 106$ 에서 각각 5 개, $\mathrm{OPH} 20$ 과 RAPD14에서 각각 2개의 다형성 밴드가 확인되었다. PIC 값은 평균 0.48 로 나타났으며, 각각의 PIC 값은 84 번 프라이 머는 $0.06,173$ 번은 $0.10,174$ 번은 $0.99, \mathrm{~B} 18$ 은 $0.74, \mathrm{OPGQ} 1$ 은 0.96, OPH20은 0.66, OPI01은 0.74, UBC106은 0.92, $\mathrm{RAPD} 14$ 는 0.16 이었고, B12와 OPG5는 각각 0.00 으로 분석되 었다(Table 2). 브라질의 20개 밀 품종의 유전적 다양성 평가에 서 $\mathrm{OPH} 20, \mathrm{OPI} 01, \mathrm{OPI} 05, \mathrm{OPG} 12, \mathrm{OPH} 01$ 등 5 개의 다형성은 $83 \%$ 로 나타났다(De Freitis et al. 2000). 이들 중 OPH20와 


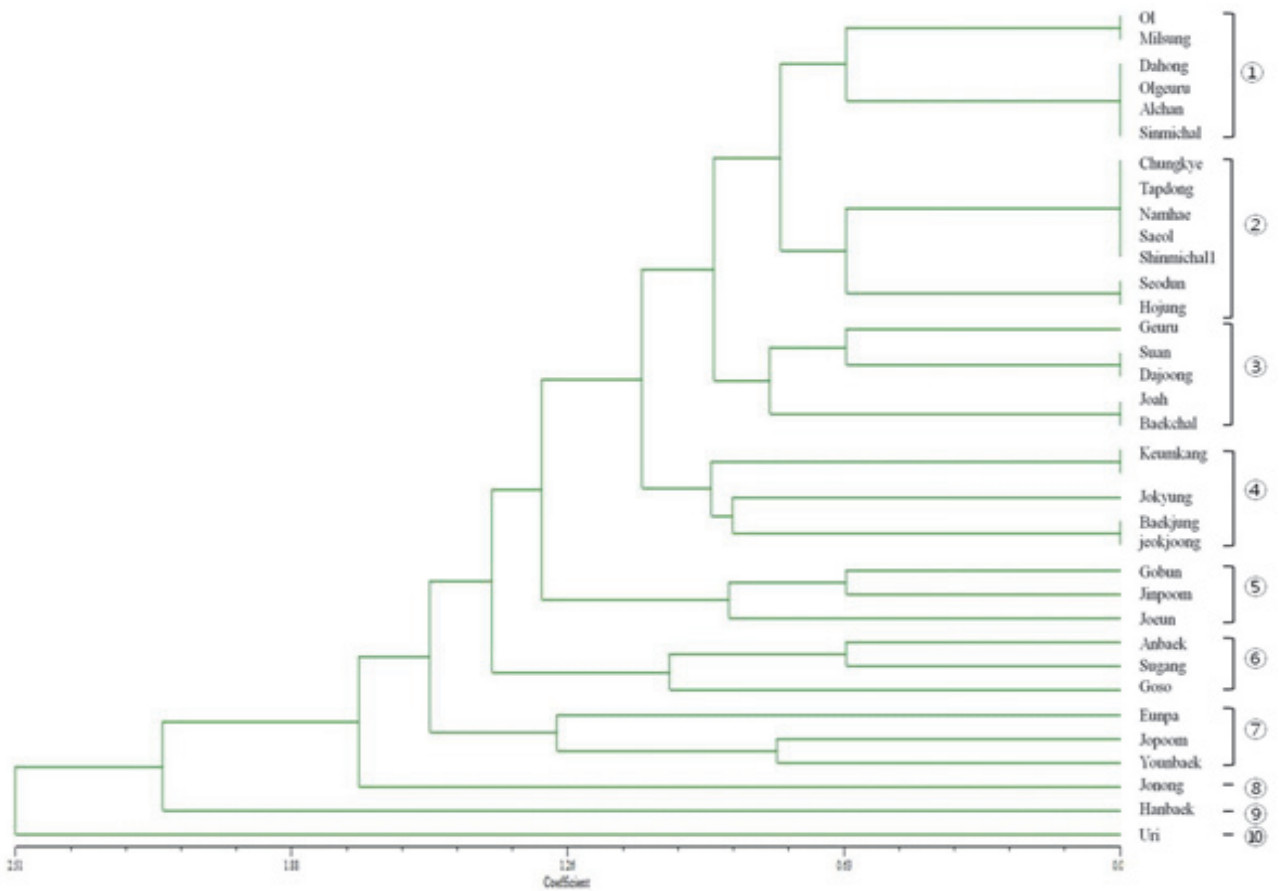

Fig. 2. Dendrogram presenting genetic relationships among 35 Korean wheat cultivars. Ten association groups were formed.

OPI01 등 2개 프라이머는 한국밀 35개 품종에서도 74 90\%(PIC 0.66 - 0.74)으로서 매우 높게 나타났다(Table 2). $\mathrm{OPI} 01$ 은 인도의 밀 품종 분석에서 377 과 $2,529 \mathrm{bp}$ 에서 7 개의 다형성 밴드가 확인되었지만, 한국밀 품종과 같이 뚜렷한 유전자 형이 나타나지 않았고, $\mathrm{OPH} 20$ 은 17 개의 많은 다형성 밴드가 확인되었고 품종 특이적 밴드가 $647 \mathrm{bp}$ 와 $403 \mathrm{bp}$ 에서 확인되었 다(Grewal et al. 2007). 그러나 한국밀 품종 분석에서 OPI01은 4 개, $\mathrm{OPH} 20$ 은 2개의 다형성 밴드만 확인되었다(Table 2, Fig. 1). 이 같은 결과는 인도와 한국밀의 지역적 위치에 따른 유전적 다양성이 매우 크기 때문인 것으로 생각된다. 한국밀 품종 분석에 사용된 11 개 프라이머의 다형성 밴드 수는 기존 보고된 것 보다 적었지만, 높은 다형성과 재현성을 나타냈기 때문에 데이터 분석 에 사용될 수 있었다(Table 2).

11 개 RAPD 프라이머 중 품종 특이적으로 증폭되는 밴드가 뚜렷하게 나타나는 프라이머는 84, 173, 174, OPGQ1, RAPD14, OPH20 등 6개였다. 다른 프라이머에서 확인된 품종 특이적 밴드는 매우 희미하게 확인되어 확실하게 구분할 수 없어 분석에서 제외시켰다(Fig. 1). 84번 프라이머를 이용하여 PCR 수행한 결과 우리를 제외한 34개 품종에서 3 개의 밴드가 증폭되었다. 173 번은 우리와 조농 등 2 개 품종에서 2 개의 밴드가 나타났고, 다른 품종들은 3 개의 밴드가 나타났다. 174번은 은파,
고분, 진품, 조은 등 4 개 품종에서 $320 \mathrm{bp}$ 의 밴드가 확인되었다. $\mathrm{OPGQ1}$ 는 4개의 주요 밴드 중 $415 \mathrm{bp}$ 의 밴드는 금강, 조은, 조경, 연백, 백중, 조중, 백찰 등 7 개 품종에서만 확인되었다. $\mathrm{OPH} 20$ 은 탑동과 남해 등 2개 품종에서 $800 \mathrm{bp}$ 와 $650 \mathrm{bp}$ 의 밴드가 각각 희미하게 나타났다. 이들 6 개의 평균 PIC 값은 0.49 였다(Table 2). RAPD14번은 32개 품종을 제외한 은파, 조품, 연백 등 3 개 품종에서 $316 \mathrm{bp}$ 의 밴드가 확인되지 않았다 (Fig. 1). 분석을 통하여 품종 특이적 밴드를 나타내는 마커 중 174, OPGQ1, RAPD14 등 3개는 한국밀 품종 판별용 마커로 직접적으로 사용이 가능할 것으로 판단된다.

\section{유전적 유연관계 분석}

$\mathrm{RAPD}$ 를 이용한 마커의 다형성 분석을 통해 확인된 밴드 중 $100-1,000 \mathrm{bp}$ 사이의 DNA 밴드를 데이터화 하였다. 즉, $\mathrm{PCR}$ 을 통해 증폭된 밴드와 증폭되지 않은 밴드를 각각 ' 1 '과 ' 0 '으로 데이터화하였다. 그 중에서 증폭된 밴드의 확인이 불확 실한 것은 데이터에서 제외시켰다. RAPD 데이터를 사용하여 계통학적 분석결과 10 개의 그룹이 확인되었다(Fig. 2). 한국밀 품종 중 우리가 아웃그룹(10)으로 형성되었고 한백(9)과 조농 (8)이 그 다음 그룹으로 각각 형성되었다. (1) 그룹에서 올, 밀성, 다홍, 올그루, 알찬, 신미찰 등 6 개 품종이 확인되었다. 
Table 3. Information of analyzed sequences of cultivar specific DNA fragments from the result of RAPD analysis.

\begin{tabular}{|c|c|c|c|c|}
\hline $\begin{array}{l}\text { Primer } \\
\text { name }\end{array}$ & $\begin{array}{l}\text { The length of } \\
\text { analyzed } \\
\text { sequences (bp) }\end{array}$ & Predicted gene function sorted by NCBI & E-value & $\begin{array}{l}\text { Query } \\
\text { coverage }(\%)\end{array}$ \\
\hline 173 & 278 & $\begin{array}{l}\text { Brachypodium distachyon transcription elongation factor } 1 \text { homolog } \\
\text { (LOC100834870) }\end{array}$ & $2 \mathrm{e}-15$ & 34 \\
\hline 173 & 319 & $\begin{array}{c}\text { Unknown, Triticum aestivum chromosome 3B, genomic scaffold, } \\
\text { cultivar Chinese Spring }\end{array}$ & $2 \mathrm{e}-72$ & 99 \\
\hline 174 & 298 & Triticum monococcum subsp. aegilopoides clone TbBAC30, complete sequence & $4 \mathrm{e}-119$ & 96 \\
\hline OPGQ1 & 415 & $\begin{array}{c}\text { Unknown, Triticum aestivum chromosome 3B, genomic scaffold, } \\
\text { cultivar Chinese Spring }\end{array}$ & $6 e-151$ & 93 \\
\hline OPH20 & 575 & $\begin{array}{c}\text { Unknown, Triticum aestivum chromosome 3B, genomic scaffold, } \\
\text { cultivar Chinese Spring }\end{array}$ & $1 \mathrm{e}-173$ & 84 \\
\hline RAPD14 & 316 & $\begin{array}{l}\text { Unknown, Triticum aestivum chromosome 3B, genomic scaffold, } \\
\text { cultivar Chinese Spring }\end{array}$ & $1 \mathrm{e}-62$ & 93 \\
\hline
\end{tabular}

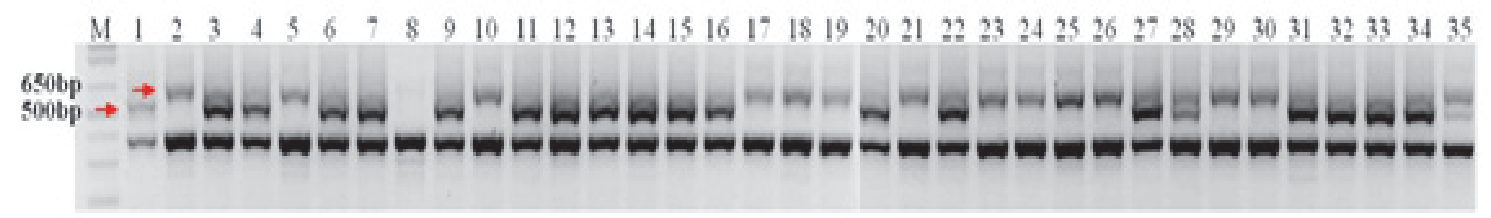

Fig. 3. The profiles of PCR amplified DNA fragments using developed SCAR markers, KWSM011, in 35 Korean wheat cultivars. The number indicates Korean wheat cultivars. The arrows indicate differential amplified DNA fragments between cultivars.

올과 밀성의 RAPD 다형성은 같았지만, 다른 4 개 품종의 다형성 은 각각 같은 것으로 확인되었다. (2) 그룹에서 7개의 품종이 함께 나타났으며, 청계, 탑동, 남해, 새올, 신미찰1호의 유전자형 이 같고 서둔과 호중의 유전자형이 같은 것으로 확인되었다. (3) 그룹에서 5 개의 품종이 확인 되었으며, 수안과 다중, 조아와 백찰의 유전자형은 각각 같은 것으로 나타났다. 금강, 조경, 백중, 적중 등 4개의 품종은 (4) 그룹에서 형성되었으며, 백중과 적중의 유전자형이 같게 나타났다. (5) 그룹은 고분, 진품, 조은 등 3 개의 품종, (6) 그룹은 안백, 수강, 고소 등 3개 품종, (7) 그룹은 은파, 조품, 연백 등 3 개의 품종으로 각각 그룹화 되었다(Fig. 2). 본 연구에 사용된 품종은 모두 6 배체 밀로서 품종 간 다양성이 크게 나타나지는 않았지만, 조농, 한백, 우리는 다른 품종과의 유연관계가 먼 것으로 나타났다. 몇몇 RAPD 마커에서 RAPD-PCR에 의한 재현성과 다형성이 확인되었다. 그리고 $\mathrm{RAPD}$ 는 빠르고 경제적 이점이 크기 때문에 밀의 육종에서 유용성이 크다. 특히 많은 수의 유전자원 평가에 유용하며 중요한 형질, 유전자 또는 quantitative trait loci (QTL)와 연관마커 분석에 사용될 수 있다(Grewal et al. 2007).

\section{품종 특이적 프라이머 디자인 및 적용}

7개의 품종 특이적 단편이 RAPD 프라이머 분석에서 확인되 었다(Table 3). 이들 단편에 대한 유전자 정보를 분석하기 위해 NCBI(https://blast.ncbi.nlm.nih.gov)와 TIGR(http://blast.jcv i.org/er-blast/index.cgi?project=ath1) 등 데이터베이스를 활용 하였지만, 173 번에서 분리된 단편을 제외한 나머지 DNA에 대한 기능은 알 수 없었다. 173 번에서 분리된 $278 \mathrm{bp}$ 크기의 단편은 distachyon transcription factor 유전자의 일부와 일치하 지만 유사도가 매우 낮게 나타났다 (Table 3). 6개 염기서열을 이용하여 프라이머를 디자인하였고, 품종에 적용한 결과 $\mathrm{OPH} 20$ 의 DNA 단편 염기서열에서 유래된 프라이머 KWSM011(F: GGGAGACATCACCGGGCTGTACATG-3', R: 5'-TCTTG CCCTCCAATACATAGTCC-3')는 품종에 적용했을 때, 500 $\mathrm{bp}$ 와 $600 \mathrm{bp}$ 등 2개의 구별 가능한 밴드가 확인되었다(Fig. 3). 그러나 나머지 5 개 프라이머는 품종 간 차이를 나타내지 않아 품종 특이적 마커로서는 적합하지 않았다. 현재 한국밀 품종 판별용 마커는 Inter simple sequence repeat (ISSR)와 Amplific ation fragment length polymorphism(AFLP) 등의 분석을 통하 여 10 개 세트가 개발되어 있다(Son et al. 2013, Son et al. 
2014). 이들 10 개 마커 세트를 이용하여 품종 32 개 중 27 개를 구별할 수 있다. 본 연구에서 3개의 RAPD 마커 및 KWSM011 등 4 개 마커는 새롭게 호중, 조중, 백찰 등 3 개 품종이 추가된 35 개 품종으로부터 개발된 것으로서 이들 마커 조합을 이용하여 은파, 조품, 연백, 적중 등 4 개 품종을 구별할 수 있다. 이들 4 개 마커와 이미 개발된 11 개 마커 세트를 이용하면 더 많은 품종을 판별해낼 수 있지만, 3 개 품종이 추가되었기 때문에 기존의 마커 조합과는 따로 사용하는 것이 더 효율적일 것으로 생각된다.

\section{적 요}

35 개 한국밀 품종의 유전성 다양성과 품종 특이적 마커를 개발하기 위해 11 개의 RAPD 마커를 평가하였다. PCR 분석 결과 평균 5.2개의 다형성 밴드가 확인되었으며, 평균 PIC 값은 0.48 이었다. 뚜렷한 품종특이적 밴드가 나타난 RAPD 프라이머 는 84, 173, 174, OPGQ1, RAPD14, OPH20 등 6개였으며, 이 중 OPGQ1, 174, RAPD14 등 3개는 품종 판별용 RAPD 마커로서 사용이 가능할 것으로 판단되었다. 또한 $\mathrm{OPH} 20$ 에서 품종특이적 단편을 이용하여 새로 디자인된 KWSM011는 품종 간 뚜렷하게 차이를 보이는 2 개의 밴드가 확인되어 품종 판별용 마커로서 이용할 수 있었다. OPGQ1, 174, RAPD14, KWSM011 등 4개의 마커를 이용하여 35 개 품종 중 은파, 조품, 연백, 적중 등 4개 품종을 구별할 수 있었다. 몇몇 품종 특이적 DNA 단편의 유전자 정보는 RAPD173 프라이머를 이용하여 증폭된 $278 \mathrm{bp}$ 의 DNA 단편 이외는 대부분 정확한 유전자 기능 이 알려져 있지 않았다. 유전적 연관관계 분석을 통해 10 개의 연관 그룹이 형성되는 것을 확인하였고, 한국밀 품종 중 우리, 한백, 조농 등 3 개 품종은 다른 품종과의 다양성이 큰 것으로 나타났다.

\section{사 사}

본 연구는 2017년도 농촌진흥청 국립식량과학원 박사후연수 과정지원사업(PJ012464042017)에 의해 이루어진 것임.

\section{REFERENCES}

1. Chalmers KJ, Waugh R, Sprent JI, Simons AJ, Powell W. 1992. Detection of genetic variation between and within populations of Gliricidia sepium and G. maculate using
RAPD markers. Heredity 69: 465-472.

2. Chen JM, Xue X, Cai D, Jensen KB, Chatterton NJ. 1998. Development and characterization of Elymus rectisetus species and accession-specific RAPD markers. In: A. E. Slinkard (ed.), Proc. $9^{\text {th }}$ Int. Wheat Genet. Symp. 3: 98-101. Univ. Extension Press. Univ. of Saskatchewan, Saskatoon.

3. De Freitas LB, Jerusalinsky L, Bonatto SL, Salzano FM. 2000. Extreme homogeneity among Brazilian wheat genotypes determined by RAPD markers. Pesqui Agropecu Bars. 35: 2255-2260.

4. Dweikat I, Ohm H, Machenzie S, Patterson F, Cambron S, Ratcliffe R. 1994. Association of a DNA marker with the hessian fly resistance gene $H 9$ in wheat. Theor. Appl. Genet. 89: 964-968.

5. Gupta PK, Mir RR, Mohan A, Kumar J. 2008. Wheat genomics: present status and future prospects. Itnl. J. Plant Genomics 2008: 896451, 36pages.

6. Grewal S, Pushpa K, Malik R, Jain S, Jain RK. 2007. Assessment of genetic diversity among some Indian wheat cultivars using random amplified polymorphic DNA (RAPD) markers. Indian J Biotech. 6: 18-23.

7. He S, Ohm H, Mackenzie S. 1992. Detection of DNA sequence polymorphisms among wheat varieties. Theor. Appl. Genet. 84: 573-578.

8. Kuchel H, Ye G, Fox R, Jefferies S. 2005. Genetic and economic analysis of a targeted marker-assisted wheat breeding strategy. Mol. Breeding 16: 67-78.

9. Landry BS, Li RQ, Cheung WY, Graner RL. 1994. Phylogeny analysis of 25 apple rootstocks using RAPD markers and tactical gene tagging. Theor. Appl. Genet. 89: 847-852.

10. Liu BH. 1998. Statistical genomics: linkage, mapping and QTL analysis. CRC Press, Boca Raton.

11. Nesbitt KA, Potts PM, Vaillancourt RE, West AK, Reid JB. 1995. Partioning and distribution of RAPD variation in a forest tree species, Eucalyptus globules (Myrtaceae). Heredity 74: 628-637.

12. Pakniyat H, Tavakol E. 2007. RAPD Markers associated with drought tolerance in bread wheat (Triticum aestivum L.). Pak. J. Biol. Sci. 10: 3237-3239.

13. Park CS, Roberto JP, Baik BK, Kang CS, Heo HY, Cheong YK, Woo SH. 2009. Allelic variation of glutenin, granule-bound starch synthase I and puroindoline in Korean wheat cultivar. Koran J. Crop Sci. 54: 181-191. 
14. Rafalski JA, Tingey SV. 1993. Genetic diagnostics in plant breeding: RAPDs, Microsatellites and Machines. Trends. Genet. 9: 275-280.

15. Rohlf FJ. 1998. NTSYS-PC. Numerical taxonomy and multivariate analysis system, version 2.00. Exeter Software, Setauket, NY.

16. Son JH, Kim KH, Shin SS, Kim HS, Kim NS, Hyun JN, Shim SI, Lee CK, Park KG, Kang CS. 2013. ISSR-derived Molecular Markers for Korean Wheat Cultivar Identification. Plant Breed. Biotech. 1: 262-269.

17. Son JH, Kim KH, Shin SH, Choi ID, Kim HS, Cheong
YK, Lee CK, Lee SI, Choi JY, Park KG, Kang CS. 2014. Development of SCAR markers for Korean wheat cultivars identification. Plant Breed. Biotech. 2: 224-230.

18. Wang RRC, Cheng J, Joppa LR. 1995. Production and identification of chromosome specific RAPD markers for durum wheat 'Langdon' disomic substitution lines. Crop Sci. 35: 886-888.

19. Wiliams JGK, Kubelik ARK, Livak JL, Rafalski JA, Tingey SV, 1990. DNA polymorphisms amplified by random primers are useful as genetic markers. Nucl. Acids. Res. 18: 6531-6535. 